\section{Catalytic Asymmetric Cross-Coupling of Styrenyl Aziridines}

Metal-Catalyzed

Asymmetric

Synthesis and

Stereoselective

Reactions

\section{Key words}

nickel catalysis

cross-coupling

aziridines

ring opening

arylphenethylamines<smiles>[SnH3]NCC[C]c1ccccc1</smiles>

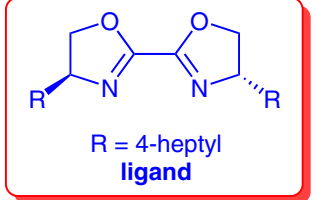

Selected examples:<smiles>COc1ccc([C@H](CNS)c2ccccc2)cc1</smiles><smiles>N#Cc1ccc([C@H](CN[AsH3])c2ccccc2)cc1</smiles>

$71 \%$ yield, $91 \%$ ee

$66 \%$ yield, $78 \%$ ee<smiles>CCOC(=O)c1cccc([C@@H](CN[AsH3])c2ccccc2)c1</smiles><smiles>CCCCCCC(c1ccccc1)c1ccc2ccccc2c1</smiles>

$59 \%$ yield, $94 \%$ ee

$65 \%$ yield, $94 \%$ ee<smiles>CC(=O)Oc1ccc([C@@H](CN[SH3+])c2ccc(C(C)=O)cc2)cc1</smiles>

$78 \%$ yield, $90 \%$ ee<smiles>CCNC[C@H](c1ccc(OC)cc1)c1ccc(C(C)=O)cc1</smiles>

$47 \%$ yield, $88 \%$ ee<smiles>CCCCCCCC(c1ccccc1)c1ccc(C(C)(F)F)cc1</smiles>

$76 \%$ yield, $90 \%$ ee<smiles>CCCCCCCC(c1ccccc1)c1ccc2c(c1)CCO2</smiles>

$71 \%$ yield, $92 \%$ ee<smiles>COc1ccccc1</smiles><smiles>CC(CN[AsH3])c1ccc(C(F)(F)F)cc1</smiles>

$67 \%$ yield, $85 \%$ ee<smiles>Clc1ccc([C@@H](CN[AsH3])c2ccccc2)cc1</smiles>

$65 \%$ yield, $87 \%$ ee<smiles>CSCCNC[C@@H](c1ccccc1)c1cccc(Cl)c1</smiles>

$67 \%$ yield, $90 \%$ ee<smiles>CCOC(=O)c1cccc([C@@H](CN[AsH3])c2ccc(F)cc2)c1</smiles>

$45 \%$ yield, $91 \%$ ee
Significance: The metal-catalyzed cross-coupling reaction is one of the most useful reactions for forming $\mathrm{C}-\mathrm{C}$ bonds. A nickel-catalyzed reductive cross-coupling of racemic styrenyl aziridines with aryl halides in the presence of a new bisoxazoline ligand gave highly enantioenriched 2-arylphenethylamines in good yields and with excellent enantioselectivity.

SYNFACTS Contributors: Hisashi Yamamoto, Amit Banerjee Synfacts 2017, 13(07), 0709 Published online: 19.06.2017 Dol: 10.1055/s-0036-1590537; Reg-No.: H06617SF
Comment: The method has a broad substrate scope and tolerates various functional groups. Moreover, variation in the enantioselectivity depending on the ligand was well explained by means of multivariate analysis. A detailed ligand study was carried out to determine the origin of the observed selectivity. The present method can be useful in the synthesis of various chiral 2-arylphenethylamine moieties present in bioactive molecules and pharmaceutically important molecules. 